\title{
Identification and ranking effective factors on establishment of green supply chain management in railway industry
}

\author{
Gholamreza Hashemzadeh, Mahmoud Modiri and Zakieh Rahimi*
}

Department of Management and Accounting, South Branch, Islamic Azad University, Tehran, Iran

\section{H R O N I C L E}

Article history:

Received December 10, 2013

Received in revised format

16 March 2014

Accepted May 202014

Available online

May 292014

Keywords:

Supply Chain

Green Supply Chain Management

Environmental Requirements

DEMATEL

Fuzzy TOPSIS

\begin{abstract}
A B S T R A C T
Globalization, intensification of governmental and non-governmental organization's provisions and squeeze and the demand of clients about concerning environmental affairs have motivated many organizations to start considering Green Supply Chain management in order to facilitate environmental and economic functions. Administration of green supply chain management unifies the management of supply chain with environment requirements during the functioning of levels of supply chain. This paper aims to identify green supply change management's factors in order to facilitate implementation of green supply chain management in rail industry. Thus, the effective factors of green supply chain management establishment are extracted and the method of interactions between sub-scales is studied by DEMATEL technique. The result specifies that reduction of production loss sub-scale is the most effective factor on other agents. In addition, the effective elements peered out by fuzzy TOPSIS that the scale of loss management stands on the first ranking and improvement of production process and interior environment management scales stand on the second and the third level and other scales follow them.
\end{abstract}

\section{Introduction}

According to previous standpoints, the aim of supply chain was improvement of functioning in order to improve firms' productivity and profitability, but enhancement of supply chain's environmental function and the importance of social charges and environmental destruction was disregarded (Handfield \& Nichols, 2005). Recently, because of rapid industrialization of societies, there are intensive tendencies to environmental shortcomings (Zhu et al., 2008) and most governments start employing environmental preservation regulations. These days, we hear more about the terms like environment friendly Raw materials, reduction of fossil fuel consumption and recycling losses (Hajmohammad et al., 2013; Koplin et al., 2007). Therefore, the sequence of Green Supply Chain Management (GSCM) appeared (Imani \& Ahmad, 2009). Therefore, implementation of GSCM among various industries especially in rail industry relies on its whole level of lifecycle. Hence, the main question of this research is to identify effective elements of implementation and establishment

* Corresponding author

E-mail address: rahimisarah@yahoo.com (Z. Rahimi)

(C) 2014 Growing Science Ltd. All rights reserved. doi: $10.5267 /$ j.uscm.2014.5.007 
of GSCM in rail industry simultaneously with supply chain general approaches and concerning environmental dilemmas. The aim of implementation of this research is also to identify and to rank effective elements on implementation of Green Supply Chain in rail industry in Iran.

\section{Green supply chain management}

By increasing the verity of client's concerned expectations toward the patterns, organizations interested in increasing their flexibility in production lines and started improving and developing new products for customer's satisfaction, which has created the concept of Supply Chain (Lewis \& Gretsakis, 2001). Supply Chain, is the entire activities associated with progress and exchange of goods from raw material level to deliver final consumer and the related information flow (Safarzadeh et al., 2011). Today, because of consumer's concern about environment and state environmental supporting organizations for optimum consumption of energy many producers have tried to supply energy efficient products (Jen Lin et al., 2011). Therefore, concerning the growing anxiety about environment, beside the industry development, in SCM process the environment pollution should be regarded (Rao \& Holt, 2005). Supply Chain Management plays essential role in preventing human, time and financial source loss (Stevels, 2002; Shen, 2013). One of the implementation tools of green supply chain is associated with Green Supply Chain (Balo et al., 2012; Chandra \& Fisher, 2003). Greening the Supply Chain is a new concept (Samson \& Simpson, 2008). Therefore, it can be declared that the basis of GSCM is on unified management of environment and supply chain management for controlling environmental destructive effects in a lifecycle of production with information allotments and cooperation of all members of supply chain (Balon et al., 2012).

\subsection{The Impressive elements for establishment of Green Supply Chain Management}

Some effective elements for establishment of Green Supply Chain in organizations, shown in Table 1:

\section{Table 1}

Effective elements on Green Supply Chain establishment

\begin{tabular}{|c|c|}
\hline Feature & References \\
\hline $\begin{array}{l}\text { 1. Environmental Competence 2. Pollution Control 3. Environmental } \\
\text { Management } 4 \text {. Environmental Collaboration 5. Green Production }\end{array}$ & Akman \& Piskin, 2013; Cousins et al., 2004 \\
\hline $\begin{array}{l}\text { 1. Interior Environmental Management 2. Green Supply Chain Management } \\
\text { external methods 3.Investment Retrieval 4.Environmental Compatible } \\
\text { Sketching }\end{array}$ & Zhu \& Sarkis, 2004; Hillary, 2000 \\
\hline 1. Packaging vicissitude or reconciliation 2. Green Marketing & Envirowise, 2001; Zhu \& Sarkis, 2006 \\
\hline $\begin{array}{l}\text { 1. Green Purchase 2.Green Sketching 3. Product Resumption 4.Collabrating } \\
\text { with suppliers and customers. }\end{array}$ & (Lin, 2013; Farahani, 2009) \\
\hline 1. Resumption Sketch 2.Loss Management & Envirowise, 2001; Shen \& Yand Tam, 2002; Ofori et al., 2002 \\
\hline $\begin{array}{l}\text { 1.Environmental Compatible Designing 2.Green Production 3.Green } \\
\text { Purchase }\end{array}$ & $\begin{array}{c}\text { Zhu \& Sarkis, 2006; Srivastava, 2007; Starkley, 2000; Lamming \& } \\
\text { Hampson, } 1996\end{array}$ \\
\hline $\begin{array}{l}\text { 1. Green Production 2. Suppliers' demands 3. Supplier's Flexibility } 4 . \\
\text { Collaboration of Suppliers with Products' Designers 5.Clients' Demand } \\
\text { Provision }\end{array}$ & Tseng et a, 2011; Zhu \& Sarkis, 2006 \\
\hline 1. Lifecycle Assessment 2. Loss Control & Srivastava, 2007; Envirowise, 2001; Starkley, 2000; Green et al., 1996 \\
\hline $\begin{array}{l}\text { 1. Senior Management Assert 2.Middle -level Management Assert 3.Product } \\
\text { Quality Management 4.Environmental Evaluation Program 5.Certificate } \\
\text { nrehension 6. Environmental Protection Law Sunnort }\end{array}$ & Morrow \& Rondinelli, 2002; Ninlawan et al., 2010 \\
\hline $\begin{array}{l}\text { 1. Pollution Control 2. Environmental Management 3.Management Assert } \\
\text { 4.Green Designing } \\
\text { Training }\end{array}$ & Shen et al., 2013 \\
\hline $\begin{array}{l}\text { 1.Environmental Requirements Statements 2.Information Sharing } \\
\text { 2 Collahration }\end{array}$ & Theyel, 2002 \\
\hline $\begin{array}{l}\text { 1.Environmental Management 2.Supplier's Flexibility } 3 . \text { Close } \\
\text { Communication with Suppliers }\end{array}$ & Tseng, \& Chui , 2013 \\
\hline $\begin{array}{l}\text { 1. Green Designing 2. Green Market 3. Interior Management 4.Resunption } \\
\begin{array}{ll}\text { 4.Investment } & \text { 5. Investment Return }\end{array}\end{array}$ & Stevels, 2002; Eiadet et al. (2008) \\
\hline $\begin{array}{l}\text { 1.Green Distribution Procedure 2.Green Product Distribution 3. Supply } \\
\text { Chain Advanced Inspection }\end{array}$ & Bowen et al., 2001 \\
\hline
\end{tabular}


In this article regarding to revising the literature and expert's interview, there are 10 main scales with 36 sub-scales for establishment of Green Supply Chain in Railway industry have identified and by Fuzzy screening through them there are seven main scales with 20 sub-scales specified.

There are many studies associated with Green Supply Chain Management (GSCM). Lin (2013), for instance, proposed a method for assessment of GSCM by considering three scales and eight subscales selected which employing DIMATEL technique and the communication of sub-scales were identified as Green Purchase, Green Designing, Resumption, Collaboration with Legislators and Stockholders according the acquired results of DIMATEL.

Shen et al. (2013) investigated supplier's turnover in green supply chain by applying Fuzzy TOPSIS in auto industry. They identified pollution control, environmental management, management assessment, green designing, purchasing environmentally friendly materials, clean technology, and staff training as important criteria. Tseng and Chui (2013) identified tendencies towards stable environmental activities for improving supply chain in developed organizations in which the technique collective decisions in Fuzzy environment and for ranking options (Four Suppliers) 7 scales were detected. In acquired results, environmental management, supplier's flexibility and close communications of suppliers received the maximum weight compared with the other elements.

Zhu and Sarkis (2007) studied the barriers and effective motives in implementation of green supply chain in auto industry in China. Brorson et al. (2009) studied the impression of ISO14001 in three major GSCM activities in Swedish firms. Lee, et al. (2009) performed a survey for the evaluation of suppliers in GSCM to identify premier Green suppliers and collaboration with them in Green Supply Chain in LED producer companies in Taiwan with the DELFI method and Fuzzy analytical hierarchy process (AHP) in order to identify scales and options ranking studied.

Zhu et al. (2008) studied the communication and effects of two other elements in organization learning and senior management assessment on executive activities for attaining GSCM in productive firms in chain. They concluded that both elements had direct impact on organizations' turnover in field of GSCM. Securing and Muller (2008) studied the history of supply chain and Green Supply chain. Linton et al. (2007) illustrated the concepts and doctrines of stable and Green Supply Chain.

\section{Methods}

The current research concerning the functional approach and follows descriptive survey style . For gathering the information the library method and field study have been used in railway industry with sending questionnaires to experts and interviewing. The statistical community of this research is The Tehran Subway Operation Company and the statistic samples are the number of experts who are completely dominant to Green Supply Chain which they were 25 people to identification of elements and their number for ranking and identification about quality of communication through sub-scales were four people. The research's questions follow as:

1. What are the effective elements for establishment of Green Supply Chain Management in railway industry?

2. How much do these elements weight?

3. How is the efficiency and impressibility of scales and sub-scales on each other?

4. How is the ranking of elements?

In this article for analyzing data two methods of Multi Attribute Decision Making "MADM" used: fuzzy TOPSIS technique for ranking the importance of elements and DEMATEL technique for determination of communication between sub scales and their collaboration and influence. 


\subsection{DEMATEL}

DEMATEL technique performed by Gabus and Fontela (1971). DEMATEL technique is a decision making technique for utilizing experts' activities in field of extracting a system's elements and their systematic structuring and by usage of the Graphs thesis, hierarchical structure of current elements in system, including the communications counteract influence and dud effect and defines the acrimony of the numerical score and accepts the non-transmittal terms. The process of conducting DEMATEL technique follows as:

1. Modeling the Straight relevance Matrix

2. Modeling X Matrix: that each of its elements is the average of the elements in straight experts Matrix.

3. Normalizing the straight relevance Matrix:

$M=\lambda * \mathrm{X} \quad \lambda=\frac{1}{\max \sum_{j=1}^{n} a_{i j}}$

4. Total Relation Matrix:

$S=M \times(1-M)^{-1}$

5. Modeling the Casual Diagram

Aggregation of each line's elements (R) and aggregation of each column (J) so the horizontal vector $(\mathrm{R}+\mathrm{J})$ is the efficient in system and the vertical vector $(\mathrm{R}-\mathrm{J})$ is the effectiveness of each element.

\subsection{Fuzzy TOPSIS}

TOPSIS is one of the multi index decision making methods which raking " $n$ " number of options regarding the scale $\mathrm{m}$ (Asgharpour, 2011). The basis of this method is to choose an option which has the least distance with the ideal desirable answer and the most distance with the undesirable ideal answer. The Fuzzy logic can be established among different decision making techniques. One of the techniques is technique for order performance by similarity to ideal solution (TOPSIS) by employing the Fuzzy logic changing it to Fuzzy TOPSIS and we use triangular numbers for our implementation as follows,

1. Modeling the decision making Matrix:

$D=\left[\begin{array}{cccc}x_{11} & x_{12} & \cdots & x_{1 n} \\ x_{21} & x_{22} & \cdots & x_{2 n} \\ \cdots & \cdots & \cdots & \cdots \\ x_{m 1} & x_{m 2} & \cdots & x_{m n}\end{array}\right]$

If three angular Fuzzy numbers have been used, the function of $\tilde{\mathrm{x}}_{\mathrm{ij}}=\left(\mathrm{a}_{\mathrm{ij}}, \mathrm{b}_{\mathrm{ij}}, \mathrm{c}_{\mathrm{ij}}\right)$ option ( $\mathrm{i}=1,2, \ldots, \mathrm{m})$ related in $j$ scale is $(\mathrm{j}=1,2, \ldots, \mathrm{n})$. If the decision making committee consists of $k$ members and Fuzzy ranking on the $k$ members $\tilde{\mathrm{x}}_{\mathrm{ijk}}=\left(\mathrm{a}_{\mathrm{ijk}}, \mathrm{b}_{\mathrm{ijk}}, \mathrm{c}_{\mathrm{ijk}}\right)$ (three angular Fuzzy numbers) for $m$ equals to $i=1,2, \ldots, m$ and $j=1,2, \ldots, n$ regarding the combined Fuzzy ranking scales $\tilde{x}_{i j}=\left(a_{i j}, b_{i j}, c_{i j}\right)$ the options can be resulted:

$a_{i j}=\operatorname{Min}_{k}\left\{a_{i j k}\right\} . \quad b_{i j}=\frac{\sum_{k=1}^{k} b_{i j k}}{k} \cdot c_{i j}=\operatorname{Max}_{k}\left\{c_{i j k}\right\}$ 
3. Determining the weight matrix criteria

$\widetilde{\mathrm{W}}=\left[\widetilde{\mathrm{w}}_{1}, \widetilde{\mathrm{w}}_{2}, \ldots, \widetilde{\mathrm{w}}_{\mathrm{n}}\right]$

If three angular Fuzzy numbers are used, each component $w_{j}$ (components' weight) will be defined as $\widetilde{\mathrm{W}}_{\mathrm{j}}=\left[\widetilde{\mathrm{w}}_{\mathrm{j} 1}, \widetilde{\mathrm{w}}_{\mathrm{j} 2}, \widetilde{\mathrm{w}}_{\mathrm{j} 3}\right]$. If the decision making committee consists of $\mathrm{k}$ members and the number $\mathrm{k}$ member's importance is $\widetilde{W}_{\mathrm{j}}=\left(\mathrm{w}_{\mathrm{jk} 1}, \mathrm{w}_{\mathrm{jk} 2}, \mathrm{w}_{\mathrm{jk} 3}\right)$ (three angular Fuzzy number) for $\mathrm{j}=1,2, \ldots, \mathrm{n}$ ranking component Fuzzy $\widetilde{W}_{j}=\left(w_{j 1}, w_{j 2}, w_{j 3}\right)$ can be obtained from following formulation:

$w_{j 1}=\operatorname{Min}_{k}\left\{w_{\mathrm{jk} 1}\right\} \quad w_{j 2}=\frac{\sum_{k=1}^{k} w_{j k 2}}{k} \quad w_{j 3}=\operatorname{Max}_{k}\left\{w_{\mathrm{jk} 3}\right\}$

4. Scale up Fuzzy decision matrix

$\tilde{\mathrm{r}}_{\mathrm{ij}}=\left(\frac{a_{i j}}{\mathrm{C}_{\mathrm{j}}^{*}}, \frac{b_{i j}}{\mathrm{C}_{\mathrm{j}}^{*}}, \frac{c_{i j}}{\mathrm{C}_{\mathrm{j}}^{*}}\right), \quad \tilde{\mathrm{r}}_{\mathrm{ij}}=\left(\frac{a_{j}^{-}}{c_{i j}}, \frac{a_{j}^{-}}{b_{i j}}, \frac{a_{j}^{-}}{a_{i j}}\right), \mathrm{C}_{\mathrm{j}}^{*}=\max _{\mathrm{i}} \mathrm{c}_{\mathrm{ij}}, \quad a_{j}^{-}=\min _{i} a_{i j}$

So the Scaled-up FUZZY decision Matrix $(\tilde{R})$ results in following formulation:

$\tilde{R}=\left[\tilde{\mathrm{r}}_{\mathrm{ij}}\right]_{\mathrm{m} \times \mathrm{n}} \mathrm{i}=1,2, \ldots, \mathrm{m} ; \mathrm{j}=1,2, \ldots, \mathrm{n}$

5. Determination of the weighted Fuzzy decision Matrix

$\tilde{v}_{\mathrm{ij}}=\tilde{r}_{\mathrm{ij}} \cdot \widetilde{w}_{\mathrm{j}} \rightarrow \quad \tilde{V}=\left[\tilde{v}_{\mathrm{ij}}\right]_{m \times n} \quad i=1,2, \ldots, m ; \quad j=1,2, \ldots, n$
$\tilde{v}_{\mathrm{ij}}=\tilde{r}_{\mathrm{ij}} \cdot \widetilde{w}_{\mathrm{j}}=\left(\frac{a_{i j}}{\mathrm{C}_{\mathrm{j}}^{*}}, \frac{b_{i j}}{\mathrm{C}_{\mathrm{j}}^{*}}, \frac{c_{i j}}{\mathrm{C}_{\mathrm{j}}^{*}}\right) \cdot\left(w_{j 1}, w_{j 2}, w_{j 3}\right)=\left(\frac{a_{i j}}{\mathrm{C}_{\mathrm{j}}^{*}} \cdot w_{j 1} ; \frac{b_{i j}}{\mathrm{C}_{\mathrm{j}}^{*}} \cdot w_{j 2} ; \frac{c_{i j}}{\mathrm{C}_{\mathrm{j}}^{*}} \cdot w_{j 3}\right)$
$\tilde{v}_{\mathrm{ij}}=\tilde{r}_{\mathrm{ij}} \cdot \widetilde{w}_{\mathrm{j}}=\left(\frac{a_{j}^{-}}{c_{i j}}, \frac{a_{j}^{-}}{b_{i j}}, \frac{a_{j}^{-}}{a_{i j}}\right) \cdot\left(w_{j 1}, w_{j 2}, w_{j 3}\right)=\left(\frac{a_{j}^{-}}{c_{i j}} \cdot w_{j 1} ; \frac{a_{j}^{-}}{b_{i j}} \cdot w_{j 2} ; \frac{a_{j}^{-}}{a_{i j}} \cdot w_{j 3}\right)$

6. Fuzzy Positive Ideal Solution (FPIS, $A^{*}$ ) and Fuzzy Negative Ideal Solution (FNIS, $\mathrm{A}^{-}$):

$$
\begin{gathered}
A^{*}=\left\{\tilde{v}_{1}^{*}, \tilde{v}_{2}^{*}, \ldots, \tilde{v}_{n}^{*}\right\} \quad A^{-}=\left\{\tilde{v}_{1}^{-}, \tilde{v}_{2}^{-}, \ldots, \tilde{v}_{n}^{-}\right\} \\
\tilde{v}_{i}^{*}=\operatorname{Max}_{i}\left\{\tilde{v}_{i j 1}\right\} \quad i=1,2, \ldots, m, j=1,2, \ldots, n \\
\widetilde{v}_{i}^{-}=\operatorname{Min}_{i}\left\{\tilde{v}_{i j 1}\right\} \quad i=1,2, \ldots, m, j=1,2, \ldots, n
\end{gathered}
$$

7. Computation of distance from Ideal solution and Negative Ideal Solution:

$$
\begin{gathered}
S_{i}^{*}=\sum_{j=1}^{n} d\left(\tilde{v}_{\mathrm{ij}}, \tilde{v}_{\mathrm{j}}^{*}\right) \quad, \mathrm{i}=1,2, \ldots, \mathrm{m} \\
S_{i}^{*}=\sum_{j=1}^{n} d\left(\tilde{v}_{\mathrm{ij}}, \tilde{v}_{\mathrm{j}}^{-}\right), \quad \mathrm{i}=1,2, \ldots, \mathrm{m} \\
d_{v}\left(\widetilde{M}_{1}, \widetilde{M}_{2}\right)=\sqrt{\frac{1}{3}\left[\left(a_{1}-a_{2}\right)^{2}+\left(b_{1}-b_{2}\right)^{2}+\left(c_{1}-c_{2}\right)^{2}\right]}
\end{gathered}
$$

\section{Similarity Index Computation:}

$$
C C_{i}=\frac{S_{i}^{-}}{S_{i}^{*}+S_{i}^{-}} i=1,2, \ldots, m
$$




\section{Result}

As mentioned before, 10 main scales with 36 sub scales for esablishment of Green Chain Supply have been identified. Then with screening and weighting Fuzzy and decimal (Table 2), finally 20 subscales determined which classified in 7 major group (the main criteria) (Table 3). At last, according the results mentioned in Table 3, the sub-scales with had the heavier weights selected.

Table 3

Screening and weighting Fuzzy and decimal

\begin{tabular}{|c|c|c|c|c|c|}
\hline Name of & Scale & Sub Scale & Fuzzy Normalized & Decimal Normalized & Normalized \\
\hline \multirow{5}{*}{$\mathbf{C}_{1}$} & \multirow{5}{*}{ Interior Environmental Management } & $S_{1}$ & 0.0401571 & 0.0391694 & 0.039663 \\
\hline & & $\mathrm{S}_{2}$ & 0.0395564 & 0.0387986 & 0.039178 \\
\hline & & $\mathrm{S}_{3}$ & 0.0381238 & 0.0373154 & 0.03772 \\
\hline & & $\mathrm{S}_{4}$ & 0.0221812 & 0.0226859 & 0.022434 \\
\hline & & $\mathrm{S}_{5}$ & 0.033549 & 0.0328659 & 0.033207 \\
\hline \multirow{3}{*}{$\mathbf{C}_{2}$} & \multirow{3}{*}{ Designing Improvement } & $\mathrm{S}_{6}$ & 0.0159889 & 0.0174274 & 0.016708 \\
\hline & & $\mathrm{S}_{7}$ & 0.0203327 & 0.0212364 & 0.020785 \\
\hline & & $\mathrm{S}_{8}$ & 0.0249538 & 0.0250624 & 0.025008 \\
\hline \multirow{8}{*}{$\mathrm{C}_{3}$} & \multirow{8}{*}{ Production Process Improvement } & So & 0.0269871 & 0.0268489 & 0.026918 \\
\hline & & $\mathrm{S}_{10}$ & 0.0260629 & 0.0261073 & 0.026085 \\
\hline & & $\mathrm{s}_{11}$ & 0.0318392 & 0.0313153 & 0.031577 \\
\hline & & $\mathrm{S}_{12}$ & 0.0154806 & 0.0166689 & 0.016075 \\
\hline & & $\mathrm{S}_{13}$ & 0.0304529 & 0.0302029 & 0.030328 \\
\hline & & $\mathrm{S}_{14}$ & 0.0319778 & 0.0313827 & 0.03168 \\
\hline & & $S_{15}$ & 0.022597 & 0.227365 & 0.022667 \\
\hline & & $\mathrm{S}_{16}$ & 0.034658 & 0.0339614 & 0.03431 \\
\hline \multirow{2}{*}{$\mathrm{C}_{4}$} & \multirow{2}{*}{ Non Production resource management } & $\mathrm{S}_{17}$ & 0.033549 & 0.0328491 & 0.033199 \\
\hline & & $\mathrm{S}_{18}$ & 0.0348429 & 0.0342985 & 0.034571 \\
\hline \multirow[b]{2}{*}{$\mathrm{C}_{5}$} & \multirow{2}{*}{ Loss Management } & $\mathrm{S}_{19}$ & 0.038586 & 0.0376862 & 0.038136 \\
\hline & & $\mathrm{S}_{20}$ & 0.0374769 & 0.0365739 & 0.037025 \\
\hline \multirow{5}{*}{$\mathrm{C}_{6}$} & \multirow{5}{*}{ Education and culture building } & $\mathrm{S}_{21}$ & 0.0279113 & 0.0276411 & 0.027776 \\
\hline & & $S_{22}$ & 0.0271719 & 0.0272534 & 0.027213 \\
\hline & & $S_{23}$ & 0.0121996 & 0.0136183 & 0.012909 \\
\hline & & $\mathrm{S}_{24}$ & 0.0170518 & 0.0181689 & 0.01761 \\
\hline & & $\mathrm{S}_{25}$ & 0.0228281 & 0.0234443 & 0.023136 \\
\hline \multirow{4}{*}{$\mathbf{C}_{7}$} & \multirow{4}{*}{ Environmental external management } & $S_{2 k}$ & 0.038586 & 0.0376862 & 0.038136 \\
\hline & & $S_{27}$ & 0.0324861 & 0.0320738 & 0.03228 \\
\hline & & $\mathrm{S}_{28}$ & 0.0371534 & 0.0362031 & 0.036678 \\
\hline & & $S_{29}$ & 0.0319778 & 0.0313153 & 0.031647 \\
\hline \multirow{2}{*}{$\mathrm{C}_{8}$} & \multirow{2}{*}{ Final production turnover improvement } & $S_{30}$ & 0.0288817 & 0.0287366 & 0.028809 \\
\hline & & $\mathrm{S}_{31}$ & 0.030268 & 0.0298321 & 0.03005 \\
\hline \multirow{3}{*}{$\mathrm{C}_{9}$} & \multirow{3}{*}{ Logistic } & $S_{32}$ & 0.0207486 & 0.0212364 & 0.020993 \\
\hline & & $\mathrm{S}_{33}$ & 0.0169131 & 0.0181858 & 0.017549 \\
\hline & & $\mathrm{S}_{34}$ & 0.0155268 & 0.017006 & 0.016266 \\
\hline \multirow{2}{*}{$\mathrm{C}_{10}$} & \multirow{2}{*}{ External impressions } & $S_{35}$ & 0.0254621 & 0.0257365 & 0.025599 \\
\hline & & $\begin{array}{l}\mathrm{S}_{35} \\
\mathrm{~S}_{36}\end{array}$ & 0.0154806 & 0.0166689 & 0.016075 \\
\hline
\end{tabular}

Table 3

Descending order of sub-scales by Normalized weight

\begin{tabular}{lcc}
\hline Sub Scale & Name of Sub Scale & Normalized Weight \\
\hline Senior and Middle Management Assert & $\mathrm{S}_{1}$ & 0.039663 \\
Obtaining environmental management certificates & $\mathrm{S}_{2}$ & 0.039178 \\
Loss Decrease & $\mathrm{S}_{19}$ & 0.038136 \\
Obtaining ISO1400 Certificate by Suppliers & $\mathrm{S}_{26}$ & 0.038136 \\
Environmental policies and politics & $\mathrm{S}_{3}$ & 0.03772 \\
Waste management System & $\mathrm{S}_{20}$ & 0.037025 \\
Compliance the environmental guidelines by suppliers & $\mathrm{S}_{28}$ & 0.036678 \\
Modifying consumption patterns & $\mathrm{S}_{18}$ & 0.034571 \\
Optimizing energy consumption & $\mathrm{S}_{16}$ & 0.03431 \\
Implementation of environmental audits & $\mathrm{S}_{5}$ & 0.033207 \\
Management and control of harmful plants & $\mathrm{S}_{17}$ & 0.033199 \\
Selecting and evaluation of suppliers' performance & $\mathrm{S}_{27}$ & 0.03228 \\
Reduce production waste & $\mathrm{S}_{14}$ & 0.03168 \\
Cooperation and exchange of views with stockholders & $\mathrm{S}_{29}$ & 0.031647 \\
Reduce emissions by internal processes & $\mathrm{S}_{11}$ & 0.031577 \\
Reverse logistics system & $\mathrm{S}_{13}$ & 0.030328 \\
Adopting of clean technology equipment & $\mathrm{S}_{31}$ & 0.03005 \\
Emission reduction due to final production & $\mathrm{S}_{30}$ & 10 \\
Participation of all employees & $\mathrm{S}_{21}$ & 11 \\
Increasing knowledge and awareness & $\mathrm{S}_{22}$ & 12 \\
\hline
\end{tabular}

Next, by implementation of DMATEL technique the amount of R+J, R-J and R, J are computed shown in Table 4. 
Table 4

The summary of calculation for $(\mathrm{R}+\mathrm{J}),(\mathrm{R}-\mathrm{J}),(\mathrm{R}),(\mathrm{J})$

\begin{tabular}{|c|c|c|c|c|c|}
\hline Priority order & Name of Sub Scale & R-J & Priority order & Name of Sub Scale & $\mathrm{R}+\mathrm{J}$ \\
\hline 1 & $\mathrm{C5}$ & 1.459 & 1 & $\mathrm{C} 13$ & 6.307 \\
\hline 2 & $\mathrm{C} 1$ & 1.415 & 2 & $\mathrm{C} 2$ & 6.134 \\
\hline 3 & C19 & 1.009 & 3 & C15 & 5.931 \\
\hline 4 & $\mathrm{C} 10$ & 0.943 & 4 & C6 & 5.870 \\
\hline 5 & $\mathrm{C} 20$ & 0.916 & 5 & $\mathrm{C} 10$ & 5.728 \\
\hline 6 & $\mathrm{C} 4$ & 0.644 & 6 & C5 & 5.716 \\
\hline 7 & C7 & 0.34 & 7 & $\mathrm{C} 3$ & 5.675 \\
\hline 8 & $\mathrm{C} 17$ & 0.311 & 8 & C7 & 5.490 \\
\hline 9 & $\mathrm{C} 14$ & 0.247 & 9 & $\mathrm{C} 16$ & 5.437 \\
\hline 10 & C8 & -0.05 & 10 & $\mathrm{C} 18$ & 5.214 \\
\hline 11 & $\mathrm{C} 11$ & -0.24 & 11 & $\mathrm{C} 8$ & 5.170 \\
\hline 12 & C9 & -0.3 & 12 & $\mathrm{C} 12$ & 5.132 \\
\hline 13 & $\mathrm{C} 16$ & -0.45 & 13 & $\mathrm{C} 4$ & 5.078 \\
\hline 14 & C6 & -0.46 & 14 & $\mathrm{C} 17$ & 5.049 \\
\hline 15 & $\mathrm{C} 12$ & -0.51 & 15 & C9 & 4.843 \\
\hline 16 & $\mathrm{C} 18$ & -0.59 & 16 & C19 & 4.822 \\
\hline 17 & C2 & -0.62 & 17 & C20 & 4.664 \\
\hline 18 & $\mathrm{C} 15$ & -0.7 & 18 & $\mathrm{C} 11$ & 4.657 \\
\hline 19 & $\mathrm{C} 13$ & -1.21 & 19 & $\mathrm{C} 1$ & 4.456 \\
\hline 20 & $\mathrm{C} 3$ & -2.14 & 20 & C14 & 4.446 \\
\hline
\end{tabular}

Table 5

Linguistic variables to rank the options

\begin{tabular}{cccccccc}
\hline importance & Very poor & poor & Average poor & Akin & Average good & Good & Very good \\
\hline Fuzzy Number & $(0,0,1)$ & $(0,1,3)$ & $(1,3,5)$ & $(3,5,7)$ & $(5,7,9)$ & $(7,9,10)$ & $(9,10,10)$ \\
\hline
\end{tabular}

Table 6

Green Supply Chain Scales’ Ranking

\begin{tabular}{|c|c|c|c|c|c|}
\hline Options & contraction & $\begin{array}{l}\text { Distance from } \\
\text { Positive ideal }\end{array}$ & $\begin{array}{l}\text { Distance from } \\
\text { Negative ideal }\end{array}$ & Similarity Index & Ranking \\
\hline Loss Management & $\overline{\mathrm{A}_{4}}$ & 11.670 & 12.121 & 0.547 & 1 \\
\hline Product Process improvement & $\mathrm{A}_{2}$ & 11.461 & 12.264 & 0.517 & 2 \\
\hline Interior environmental Management & $\mathrm{A}_{1}$ & 12.185 & 11.518 & 0.509 & 3 \\
\hline Non-Production resource management & $\mathrm{A}_{3}$ & 10.590 & 12.775 & 0.486 & 4 \\
\hline Environmental external management & $\mathrm{A}_{6}$ & 18.640 & 9.433 & 0.484 & 5 \\
\hline Final production turnover improvement & $\mathrm{A}_{7}$ & 11.911 & 11.194 & 0.429 & 6 \\
\hline Education and culture building & $\mathrm{A}_{5}$ & 13.429 & 10.081 & 0.336 & 7 \\
\hline
\end{tabular}

\section{Conclusion}

Studying the literature of the research and interviewing experts, 10 scales with 36 sub-scales identified and by screening them, 7 main scales and 20 sub-scales were selected. The results of our investigation have illustrated that the reduction of production loss had the strongest impact on other sub-scales. In addition, obtaining environmental management certificates and reduction of interior product process' pollution as the other sub-scale have maintained the minority interaction with other elements. Regarding the influence of the elements, Loss reduction element has been the most influential elements among the others and the reduction of interior process' pollution sub-scale stands on the second place. Other sub-scales stand respectively on following places from the influential point of view. The obtained results from the Fuzzy TOPSIS technique illustrates that the loss management stands on first place. Therefore, the organization for implying Green Supply Chain Management should invest more on loss management element. The improvement of production process and interior environmental management stand on the second and the third place. The other 
subscales stand on other rankings. Therefore, regarding the obtained results, it is suggested that the organizations start establishing and codifying a systematic and regular plan for proper implementation of waste system for industrial waste disposal which is harmful for environment. In addition, it is expected from the company, due to the importance of the improvement of production process' element, to choose the raw material, which is not harmful for environment and to replace the substances, which are environmentally friendly. In addition, controlling the pollutants in production process plays a vital role in achieving environmental targets in Supply Chain. It is advised to the company to apply the new technologies for reduction of pollutants in inter organizational process. It's also recommended the clean technologies for optimizing the energy consuming inside the organization applied in order to prevent the resource loss.

\section{References}

Akman ,G. \& Piskin, H. (2013). Evaluating green performance of suppliers via ANP and TOPSIS. Journal of Industrial Engineering, 60,106-115

Asgharpour, J. (2011). Multi Index Decision making. $9^{\text {th }}$ ed., Tehran University Publications, Tehran.

Azar, A. (2012). Strategic Decision Making with MADM. Negah e Danesh Publications, Tehran

Balon, V., Sharma, A. K., Barua, M. K., \& Katiyar, R. (2012). A Performance Measurement of Green Supply Chain Management in Indian Auto Industries. In National Conference on Emerging Challenges for Sustainable Business (p. 1577).

Bowen, F., Cousins, P., Lamming, R, \& Faruk, A. (2001). Horses for courses: Explaining the gap between the theory and practice of green supply. Journal of greener Management International, 35, 41-60

Bowen, F., Cousins, P., Lamming, R. \& Faruk, A. (2001). The role of supply management capabilities in green supply. Production and Operations Management, 10(2), 174-189

Brorson, T., Nawrocka, D. \& Lindhqvist, T. (2009). ISO 14001 in environmental supply chain practices. Journal of Cleaner Production, 17(16), 1435-1443

Chandra, P. \& Fisher, L. (2003). Coordination of production and distribution planning. MSc Thesis, Faculty of Management, MC Gill University.

Cousins, P., Lamming, R. \& Bowen, F. (2004). The role of Risk in environment related supplier initiatives. International Journal of Operation and Production Management, 24(6), 554-565

Eiadet, M., Kelly, A., \& Roche, F. (2008). Green and Competitive? An empirical test of the meditating role of environmental innovation strategy. Journal of World Business, 43(2), 131-145

Emiliani, M.L. (2000). Supporting small businesses in their transition to lean production. International Journal of Supply Chain Management, 5(2), 66-70

Envirowise, M. (2001). Cost and environmental benefits from supply chain partnerships: Mentor guide.

Farahani, Z.R., Asgari, N. \& Davarzani, H. (2009). Supply chain and logistic in national, International and governmental environment. Springer-Verlag Berlin Heidelberg

Gabus, A. \& Fontela, E. (1971). World problems an invitation to further thought within the framework of DEMATEL. Switzerland Geneva: Battelle Geneva Research Centre.

Green, K., Morton, B., \& New, S. (1996). Purchasing and environmental management: interactions, policies and opportunities. Business Strategy and the Environment, 5(3), 188-197.

Hajmohammad, S., Vachon, S., Klassen, R. D., \& Gavronski, I. (2013). Lean management and supply management: their role in green practices and performance. Journal of Cleaner Production, 39, 312-320.

Handfield, R.B. \& Nichols, E.L. (2005). Introduction to supply chain management. Prentice Hall, New Jersey, USA.

Hillary, R. (2000). The eco-management and audit scheme, ISO 14001 and the smaller firm. Small and medium-sized enterprises and the environment: Business imperatives, 1(80), 128-147.

Imani, D, M. \& Ahmad, i,A. (2009). Green Supply Chain Management the new strategy for obtaining competition preference. Car and Industry related Engendering, 1(10), 14-19. 
Lin, R. J. (2013). Using fuzzy DEMATEL to evaluate the green supply chain management practices. Journal of Cleaner Production, 40, 32-39.

Lin, R. J., Chen, R. H., \& Nguyen, T. H. (2011). Green supply chain management performance in automobile manufacturing industry under uncertainty. Procedia-Social and Behavioral Sciences, 25, 233-245.

Kahraman, C., Sezi, C., Nüfer ,.Y. \& Murat, G. (2007). Fuzzy Multi Criteria Evaluation of Industrial Robotic Systems. Computers and Industrial Engineering, 52(4), 414-433

Koplin, J., Seuring, S. \& Mesterharm, M. (2007). Incorporating sustainability into supply management in the automotive industry: The case of Volkswagen. Journal of Cleaner Production, 15(11-12), 1053-1062

Lamming, R. \& Hampson, J. (1996). The Environment as a supply chain management issue. Journal of British Journal Management, Special issue, 45-62

Lee, A.H., Kang, H.Y., Hsu, C.F. \& Chu Hung, H. (2009). A Green supplier selection model for high-tech industry. Expert Systems with Applications, 36(4), 7914-7927

Lewis, H. \& Gretsakis, J. (2001). A Global guide to designing greener goods. Sheffield, U.K, and Greenleaf Publishing.

Linton, J.D., Klassen, R., \& Vaidvanathan, J. (2007). Sustainable supply chains: An introduction. Journal of Operation Management, 25(6), 1075-1082

Morrow, D., \& Rondinelli, D. (2002). Adopting Corporate Environmental Management Systems: Motivations and Results of ISO 14001 and EMAS Certification. European Management Journal, 20(2), 159-171.

Ninlawan, C., Seksan, P., Tossapol, K., \& Pilada, W. (2010). The implementation of green supply chain management practices in electronics industry. In Proceedings of International Multi Conference of Engineers and Computer Scientists (Vol. 8).

Ofori, G., Gang, G., \& Briffett, C. (2002). Implementing environmental management systems in construction: lessons from quality systems. Building and Environment, 37(12), 1397-1407.

Rao, P., \& Holt, D. (2005). Do green supply chains lead to competitiveness and economic performance?. International Journal of Operations \& Production Management, 25(9), 898-916.

Safarzadeh, H., Masdar, M. \& Mosveh Mobarakeh, A. (2011). Concepts Supply Chain, Thesis's and usages, $1^{\text {st }}$ ed., ketab e Mehraban e Nashr Publication, Tehran.

Samson, A. and Simpson, D. (2008). Developing strategies for green supply chain management. Journal of Operation and Production Management, 27(1), 28-48

Securing, S., \& Muller, M. (2008). From a literature review on a conceptual for sustainable supply chain management. Journal of Cleaner Production, 16(15), 1699-1710

Shen, L.Y., \& Tam, V. (2002). Implementation of environmental management in the Hong Kong construction industry. International Journal of Project Management, 20(7), 535-543

Shen,L., Olfat, L., Govindan, K., Khodaverdi, R., \& Diabat, A. (2013). A fuzzy multi criteria approach for evaluating green suppliers performance in green supply chain with linguistic preferences. Journal of Resources, Conservation and Recycling, 74,170-179

Srivastava, S. K. (2007). Green supply chain management: A state of the art literature review, International Journal of Management Review, 9(1), 53-80

Starkley, R. (2000). Environmental Management Tools, Some Options for Small and Medium Sized Enterprises and the Environment. Greenleaf Publishing Sheffield, UK

Stevels A. (2002). Green supply chain management Much More Than Questionnaires and ISO 1400, IEEE, 96-100.

Theyel, G. (2002). Customer and supplier relations for environmental performance. Journal of Greener Management International, 35, 61-69

Tseng, M. L., \& Chiu, A. S. (2013). Evaluating firm's green supply chain management in linguistic preferences. Journal of cleaner production, 40, 22-31.

Verma, R., \& Vhatkar, V. (2005). REVERSE LOGISTICS: An Important dimension of Supply Chain Management. National Instıtute of Industrial Engineering, Mumbai, PGDIE Class of. 
Wu, K. J., Tseng, M. L., \& Vy, T. (2011). Evaluation the drivers of green supply chain management practices in uncertainty. Procedia-Social and Behavioral Sciences, 25, 384-397.

Wu, J., Dunn, S. \& Forman, H. (2012). A study on green supply chain management practice among large global corporation. Journal of Supply Chain and Operation Management, 10(1), 182-194

Zhu, Q. \& Sarkis, J. (2006). An inter sectoral comparison of green supply chain management in the china: Drivers and practice. Journal of Cleaner Production, 14(5), 427-786

Zhu, Q. \& Sarkis, J. (2004). Relationships between operational practices and performance among early adopters of green supply chain management practices in Chinese manufacturing enterprises. Journal of Operation Management, 22(3), 265-289

Zhu, Q., Arkis, J. \& Lai, K.H. (2008). Green Supply Chain Management Implication for closing the loop. Journal of Transportation Research Part E: Logistics and Transportation Review, 44(1), 118.

Zhu, Q., Sarkis, J., Cordeiro, J., \& Hung Lai, K. (2008). Firm Level correlates of emergent green supply chain management practices in the Chinese context. Journal of Omega, 36(4), 577-591

Zhu, Q., \& Sarkis, J. (2007). The moderating effect of institutional pressures on emergent green supply chain practices and performance. International Journal of Production Research, 45(18-19), 4333-4355

Zhu, Q. \& Sarkis, J. (2006). An inter-sector comparison of green supply chain management in china: Drivers and practices. Journal of Cleaner Production, 14(5), 472-486. 